\title{
COMMENT
}

DOI: $10.1057 /$ s41599-018-0089-5

\section{Future cities: moving from technical to human needs}

\author{
Federico Caprotti (1D ${ }^{1}$
}

\begin{abstract}
The article argues for a foregrounding of human needs at the heart of urban societal futures. While economic, technical and environmental imperatives are understandably the focus of policymaking and governance arrangements at national and supra-national scales, defining and targeting priorities in the 'ordinary' city is key. The argument is that it is now time to place basic human needs (as enshrined both in international agreements and in the more prosaic conditions of specific cities) at the centre of thinking and planning for future cities. The piece therefore proposes that plans for urban futures start from an elaboration of contextually sensitive as well as internationally negotiated needs rather than from macro-scale and potentially ephemeral visions of glittering technological future metropoles.
\end{abstract}

\footnotetext{
${ }^{1}$ University of Exeter, Exeter, UK. Correspondence and requests for materials should be addressed to F.C. (email: F.Caprotti@exeter.ac.uk)
} 


\section{Introduction: dawn, Stellenbosch}

'At the start of the day, water is an issue. Washing, going to the toilet: this requires a longish walk downhill (and then up again!) to the tap and public toilet area. The public toilets sit in not-so-splendid isolation in the middle of a small clearing, ringed by shacks: they are awful to be in when it's hot, and scary and dangerous to use when it's dark, in part due to the lack of lighting to, from and in the facility. Some simply use a bucket and then dump it into the rivulet flowing downhill near their shack: the kids playing ball have learned to skilfully avoid the liquid as they engage in endless penalty shoot-outs. As the day progresses, paraffin stoves are lit, starting the production of fumes that are the equivalent of smoking two packets of cigarettes per day for every resident in each shack with a similar stove. Some lights are visible, from candles or from those shacks that benefit from a solar panel'-Author's ethnographic notes from a visit to Enkanini informal settlement, Stellenbosch, South Africa.

The shape of the urban future. The shape of the urban future is of ever more interest today. Internationally, a raft of global agreements aims to contribute towards the shaping of future cities. The UN's New Urban Agenda, e.g., was elaborated in the run-up to the 2016 Habitat III conference in Quito, and included an explicitly urban Sustainable Development Goal for the first time in the UN's sustainable development framework (Barnett and Parnell, 2016; Caprotti et al., 2017). Similarly, the 2016 Paris Climate Agreement focused attention on a climate regime based on climate actions by sub-state actors (Hale, 2016), including cities and actors within urban areas (Gordon and Johnson, 2017). Regionally, there is also evidence of an interest in envisioning and steering the urban future, as seen through the European Union's 2016 Pact of Amsterdam, leading to the development of the EU Urban Agenda (Olejnik, 2017). Nationally, individual countries are also involved in mapping future urban development pathways, as seen in the inclusion of urban development goals in successive national economic plans in China over the past few decades ( $\mathrm{Mu}$ et al., 2016). At the same time, cities are being seen as important actors in and of themselves in shaping specific urban pathways in a 'world of cities' (Karuri-Sebina et al., 2016, p 449); while concurrently, a large swathe of urban areas (mainly in the Global South) are theorised as 'shadow cities' (Neuwirth, 2016), existing outside the circuits of international policymaking and national, corporate-infused urban boosterism.

The contemporary focus on future cities can also be found in the circulation of oft-repeated tropes, for example around increasing rates of urbanisation and rural-urban migration. These include repeated and serial assertions of the rise of the so-called 'Urban Age' (Gleeson, 2012). More broadly, the focus on cities as key places where societal futures will play out is also reflected in the emergence of notions of the Anthropocene, conceived as an era in which human societies, and their aggregate behaviours, play a key part in shaping the world's ecosystems in new directions (Smith and Zeder, 2013).

The city is, therefore, clearly seen as a stage on which societal futures will play out. Urban areas are also a stage open to design and intervention: shaping cities for a desired (and often as-yet immaterial) future. At the time of writing, many (if not most) plans and visions for future cities are actually based on:

(a) Highly technical notions of the urban future: These visions are based on underlying notions of the future city as engineering or planning problem: future directions have to be conceptualised and shaped by technical knowledge and interventions. In this perspective, climate change, resource pressures, and socioeconomic and environmental inequalities are all the results of inefficiencies in the city-as-machine, or the city-as-organism. At the same time, it is not completely clear what the urban 'machine' actually is, or even-regardless of current interest in Big Data and urban science-how it works. From this perspective, then, the future city is a technical issue to be solved rather than an opportunity to delve into the 'black box' of urban (and wider societal) life (March and RiberaFurnaz, 2016) and to ask pressing questions about what the future holds, and could hold.

(b) An urban economic lens: Much current research into future sustainable urbanism contains within it, explicitly or implicitly, the premise that the cities of the future should be based on 'business as usual' paradigms that combine technological progress with the enshrinement of continued economic growth (Gibbs et al., 2013) and the elevation of the notion of the urban citizen as homo economicus (Rossi, 2015). Again, while it is true that cities today and, in the future, will have key economic roles and characteristics, when the socio-environmental sphere is not given adequate consideration, then a purely economic perspective misses the mark by a mile.

(c) The urban efficiency imperative: Cities of the future are often envisaged, by corporate and scholarly elites and by governments, as frictionless places where flows (of capital, goods, and knowledge) can be enabled and accelerated. At the same time, the urban efficiency imperative is used to argue for more efficient and streamlined public services, including transport and e-governance. While this imperative has its utility, it also leads to a skewed notion of the urban sphere, where those who participate in the efficient acceleration of urban life qualify as worthwhile citizens (Vanolo, 2014), while those who do not (from the less able, to the poor, to the elderly, to those who live outside of the networks of digital urbanism and trade) are sidelined and rendered as targets of control and potential oppression.

These notions can, of course, be found in materials promoting other future urban development pathways: calls for resilient cities are just one example of this (Kaika, 2017). The current trend towards envisioning the smart city as a desirable direction for future urbanism is a case in point. Smart urbanism is vaguely defined at best: it has been loosely characterised as a set of approaches that seek to make the city more efficient and economically successful through the enmeshing of digital technologies and networks within the urban fabric, leveraging rapid data processing and the availability of Big Data to enable efficiency, control, and economic opportunity in real-time or near-to-real-time. Today's clarion calls for future smart cities are prevalent worldwide, from China's smart cities programme, to India's 100 smart cities initiative, to the panoply of European and North American smart urban projects. At the same time, what is common to these urban development strategies is their view of the city as a set of technical problems to be solved through the application of digital technologies; as an economic opportunity for governments and technology corporations, as well as for highly-educated and footloose 'talent'; and as a messy assemblage of social and technical life that can be rendered more efficient.

The envisioning of the future city through technical, economic, and efficiency-focused rationalities is a problem. At heart, the urban future is not primarily a technical problem, nor is it a purely economic one, although it has elements of both. To reduce the urban future to the technical or economic, to envision future urban spaces merely as enablers of greater efficiencies means reducing society to technique (Ellul, 1973). What seems to be overlooked is what Jacobs (1961) pointed to in her Death and Life of Great American Cities more than half a century ago: the human dimension. In her book, Jacobs pointedly highlighted the rift 
between the promise of high modernism in urban planning and architecture, and the resulting potential and real failures that resulted when the human dimensions of the city were not considered, accounted for, and valorised.

This short article is therefore a call to consider the human dimension, and especially the area of human needs, as the core basis and foundation on which urban futures could be usefully envisaged. The notion of human needs requires (a) a sufficiently granular definition that is both place-specific and can be related to broader agendas, and (b) contextualisation in place-specific geographical and other factors: what is a need in Johannesburg is not necessarily the same as in Urumqi, or in Calgary. What is important here is an elaboration of what is actually important in the city, on the ground, in specific places and spaces, moving away from grand stylised notions of what it means to live in cities in the 'Global South' or 'North' (Parnell and Robinson, 2012) and towards grounded notions of what is required to sustain a more equitable urban life in the 'ordinary' city (Maringanti, 2013). Nonetheless, while the definition of needs is at once basic and politically and culturally complex, it is a project that has begun (most notably with the UN and other agencies in the 20th century), and that requires sustained and continued efforts if it is to be adequately operationalised.

Needs, I argue, should be considered at multiple scales. The international scale, for example, is useful as it is the level at which significant resources, governance discourse and consciousness can be mobilised, through international agreements, treaties and diplomacy (Acuto and Rayner, 2016). The resources mobilised through action at this scale, in turn, can engender change and action at national and sub-national scales, including ordinary and everyday urban environments. At the same time, it is important to extend existing activity in local community engagement (as exemplified through the post-1992 Agenda 21) to those urban areas that are the most impoverished, that are potentially sidelined (whether intentionally or through other obstacles) from policy and other interventions, and where a human needs focus could deliver significant change. These urban areas are to be found not only in the Global South, but also in highly deprived parts of cities in middle- and high-income countries.

The latter point-of valuing specific, sub-national urban contexts-opens up the opportunity for giving serious consideration to a more rounded notion of what human needs are in specific urban contexts. It is striking that although there are repeated, frequent calls for bottom-up and participatory planning approaches, local community groups and the like are still woefully under-represented in planning processes and technical approaches to future urbanism. This is a political imperative, then: that of integrating a decentred approach to the urban into future city development priorities.

Is a consideration of human needs contradictory when juxtaposed with current imperatives focused on environmental aims? In brief, no. Since the 1970s, it has been increasingly clear that socio-economic inequalities are often produced as part and parcel of the same processes that produce socio-ecological inequalities (Swyngedouw and Heynen, 2003). While the latter may be diffuse to some extent, one of their key characteristics is that they are on the whole unevenly distributed and disproportionately affect the urban poor. Addressing current human needs through planning the city of the near future will, essentially, not require the sorts of environmental despoliation needed by current urban development models, focused as they are on growth and business-as-usual scenarios. This focus, however, require a serious commitment to and engagement with the specific notion of what a need is. In order to capture the essence of what needs are in specific contexts, a key requirement is engagement with urban citizens, not just scholars or practitioners, from a range of settings: from deprived communities in deindustrialised cities in Britain, to informal settlements in South Africa and elsewhere. These are the urban citizens who can be brought around the same table as practitioners, policymakers, and the like. This means including, but also looking beyond, the world of advocacies, NGOs, think tanks, and all others with specific and party-political agendas.

This short article opened with a vignette from a South African informal settlement on the outskirts of Stellenbosch. It closes with the urban future as envisioned in 1909 by Forster. In his The Machine Stops, Forster (1909) narrates what could be treated as a cautionary tale that rings true when considering cities simply as technical, economic and efficiency issues. The short story is set thousands of years into the future. In the story, future civilisation is homogenous, and humans have retreated to living in individual isolation in private pods within vast underground cities, connected via virtual networks. The surface of the Earth, meanwhile, is uninhabitable, as the air composition has been changed so as to make it unbreathable. The cities of the future represented by Forster are well-oiled machines that regulate their inhabitants' lives for their comfort and safety: and in so doing, reducing their humanity to the role of simple cogs in a machine. Euthanasia, banishment to the toxically polluted surface of the Earth, and ostracism are what await those who question the machine within which they live. What becomes clear, as the story progresses towards its inevitable Promethean end, is that the machine requires consent in order to function. Forster's clearly dystopian vision of the urban future, prescient in many ways, nonetheless highlights the key opportunity to move away from cities-as-technique, and towards a view of future cities as enablers of human futures.

Received: 24 October 2017 Accepted: 7 March 2018 Published online: 27 March 2018

\section{References}

Acuto M, Rayner S (2016) City networks; breaking gridlocks or forging (new) lockins? Int Aff 92:1147-1166

Barnett C, Parnell S (2016) Ideas, implementation and indicators: epistemologies of the post-2015 urban agenda. Environ Urban 28(1):87-98

Caprotti F, Cowley R, Datta A et al. (2017) The new urban agenda: key opportunities and challenges for policy and practice. Urban Res Pract 10 (3):367-378

Ellul J (1973) The technological society. Extensive underlining edition. Random House USA Inc, New York, NY

Forster EM (1909) The machine stops. Oxford and Cambridge Review, Oxford

Gibbs D, Krueger R, MacLeod G (2013) Grappling with smart city politics in an era of market triumphalism. Urban Stud 50(11):2151-2157

Gleeson B (2012) Critical commentary. The urban age: paradox and prospect. Urban Stud 49(5):931-943

Gordon DJ, Johnson CA (2017) The orchestration of global urban climate governance: conducting power in the post-Paris climate regime. Env Polit 26 (4):694-714

Hale T (2016) All hands on deck: the Paris agreement and nonstate climate action. Glob Environ Polit 16(3):12-22

Jacobs J (1961) The death and life of great American cities. Random House, New York, NY

Kaika M (2017) Don't call me resilient again!: the new urban agenda as immunology ... or ... what happens when communities refuse to be vaccinated with 'smart cities' and indicators. Environ Urban 29(1):89-102

Karuri-Sebina G, Haegeman K-H, Ratanawaraha A (2016) Urban futures: anticipating a world of cities. Foresight 18(5):449-453

March H, Ribera-Furnaz R (2016) Smart contradictions: the politics of making Barcelona a self-sufficient city. Eur Urban Reg Stud 23(4):816-830

Maringanti A (2013) Ordinary entanglements in the world city. Environ Plan A 45 (10):2314-2317

Mu B, Mayer AL, He R et al. (2016) Land use dynamics and policy implications in Central China: a case study of Zhengzhou. Cities 58(Supplement C):39-49 
Neuwirth R (2016) Shadow cities: a billion squatters, a new urban world. Routledge, London

Olejnik A (2017) Future perspectives of the implementation of EU urban agenda. Int Stud Interdiscip Political Cult J 19(1):175-188

Parnell S, Robinson J (2012) (Re)theorizing cities from the global South: looking beyond neoliberalism. Urban Geogr 33(4):593-617

Rossi U (2015) The variegated economics and the potential politics of the smart city. Territ Polit Gov 4(3):337-353

Smith BD, Zeder MA (2013) When humans dominated the Earth: archeological perspectives on the Anthropocene Anthropocene 4:8-13

Vanolo A (2014) Smartmentality: the smart city as disciplinary strategy. Urban Stud 51(5):883-898

Swyngedouw E, Heynen N (2003) Urban political ecology, justice and the politics of scale. Antipode 35(5):898-918

\section{Acknowledgements}

This work was supported by the Economic and Social Research Council [grant number ES/L015978/1 and ES/N014138/2)

\section{Additional information}

Competing interests: The author declares no competing financial interests.
Reprints and permission information is available online at http://www.nature.com/ reprints

Publisher's note: Springer Nature remains neutral with regard to jurisdictional claims in published maps and institutional affiliations.

\section{(c) (i)}

Open Access This article is licensed under a Creative Commons Attribution 4.0 International License, which permits use, sharing, adaptation, distribution and reproduction in any medium or format, as long as you give appropriate credit to the original author(s) and the source, provide a link to the Creative Commons license, and indicate if changes were made. The images or other third party material in this article are included in the article's Creative Commons license, unless indicated otherwise in a credit line to the material. If material is not included in the article's Creative Commons license and your intended use is not permitted by statutory regulation or exceeds the permitted use, you will need to obtain permission directly from the copyright holder. To view a copy of this license, visit http://creativecommons.org/ licenses/by/4.0/.

(C) The Author(s) 2018 